\title{
Article \\ The Regional Efficiency in the Use of European Agricultural Funds in Spain: Growth and Employment Analyses
}

\author{
Miguel Blanco ${ }^{1}$, Marcos Ferasso ${ }^{2}$ (D) and Lydia Bares ${ }^{1, *(D)}$ \\ 1 Department of General Economics, University of Cadiz, Avenue Enrique Villegas Velez, 2, 11002 Cadiz, Spain; \\ miguel.blanco@uca.es \\ 2 Institute of Scientific Research and Graduate School, Universidad de Lima, Av. Javier Prado Este, 4600, \\ Lima 15023, Peru; admmarcosferasso@gmail.com \\ * Correspondence: lydia.bares@uca.es; Tel.: +34-956-015-472
}

check for updates

Citation: Blanco, M.; Ferasso, M.; Bares, L. The Regional Efficiency in the Use of European Agricultural Funds in Spain: Growth and Employment Analyses. Agronomy 2021, 11, 1109. https://doi.org/ 10.3390/agronomy11061109

Academic Editor: Derek Baker

Received: 24 April 2021

Accepted: 27 May 2021

Published: 29 May 2021

Publisher's Note: MDPI stays neutral with regard to jurisdictional claims in published maps and institutional affiliations.

Copyright: (c) 2021 by the authors. Licensee MDPI, Basel, Switzerland. This article is an open access article distributed under the terms and conditions of the Creative Commons Attribution (CC BY) license (https:// creativecommons.org/licenses/by/ $4.0 /)$.

\begin{abstract}
After World War II, the European Union launched the Common Agricultural Policy. Since then, this programme has been adapting to the new economic and social realities that the European agricultural sector has been going through. Currently, a large part of this programme has been financed with the European Agricultural Guarantee Funds and the European Agricultural Fund for Rural Development. Two packages of funds have been approved in recent decades: one for the 2007-2013 and another for the 2014-2020 periods. This research has had as its main objective to determine whether the Spanish regions maintain homogeneous levels of efficiency in the use of these resources in the management of agricultural programmes from a growth and employment perspective. A methodology that is frequently used by researchers in the efficiency analyses has been chosen: data envelopment analysis. Among the main conclusions obtained are that the efficiency in the management of agricultural funds is very uneven among the studied Spanish regions. Furthermore, these differences are maintained throughout the analysed periods. This study suggests changes and proposes criteria for the allocation of European resources to finance the projects presented by the Spanish regions.
\end{abstract}

Keywords: agricultural efficiency; growth; employment; data envelopment analysis

\section{Introduction}

The Common Agricultural Policy (CAP) was created with the aim of ensuring the supply of agricultural products to the European population in an environment of food shortage caused by the effects of the Second World War [1].

Starting in the 1980s, the philosophy of this programme drastically changed. If in previous decades there was a decided public intervention on prices and quantities to ensure supply to the people, from that date onwards, there is a considerable surplus of production that could put the European agricultural system at risk [2]. This situation originated the first great reform of the system, which is known as the McSharry reform. This reform started establishing income support for farmers through payments per hectare and head of livestock and the establishment of measures to improve agricultural structures instead of traditional production aid [3].

In the year 2000, a new reform called Agenda 2000 was produced. The main points of it were the establishment of direct income support, the decrease in institutional prices, the increase in competitiveness of European agriculture, and the establishment of a rural development policy [4]. Starting in 2003, the European Union (EU) established the so-called system of direct aid to farmers known as Single Payment. New targets related to climate change, biodiversity, energy, and water management were introduced in 2008.

Subsequently, the so-called Political Agreement, established in June 2013, has been to unify the aid to farmers with compliance with a series of environmental standards greening to achieve a more sustainable CAP [5]. 
The European agricultural policy is financed mainly by the European Agricultural Guarantee Fund (EAGF) and the European Agricultural Fund for Rural Development (EAFRD). The distribution of these funds is carried out at the European level, taking into account the relative regional wealth of the member states. Specifically, there are currently three categories of regions:

- $\quad$ Less developed regions: those whose gross domestic product (GDP) per capita is less than $75 \%$ of the average GDP of the EU-27.

- Regions in transition: those whose GDP per capita is between $75 \%$ and $90 \%$ of the average GDP of the EU-27.

- More developed regions: those whose GDP per capita is above $90 \%$ of the average GDP of the EU-27.

In Figure 1, we present the distribution of funds per hectare of each Spanish region. The top regions that received most percentage of funds are the Canary Islands (25.70\%), Galicia (11.97\%), Asturias (7.72\%), Basque Country (6.70\%), Madrid (5.28\%), and Andalusia (5.05\%). The remaining 11 regions have a distribution of funds below $5 \%$.

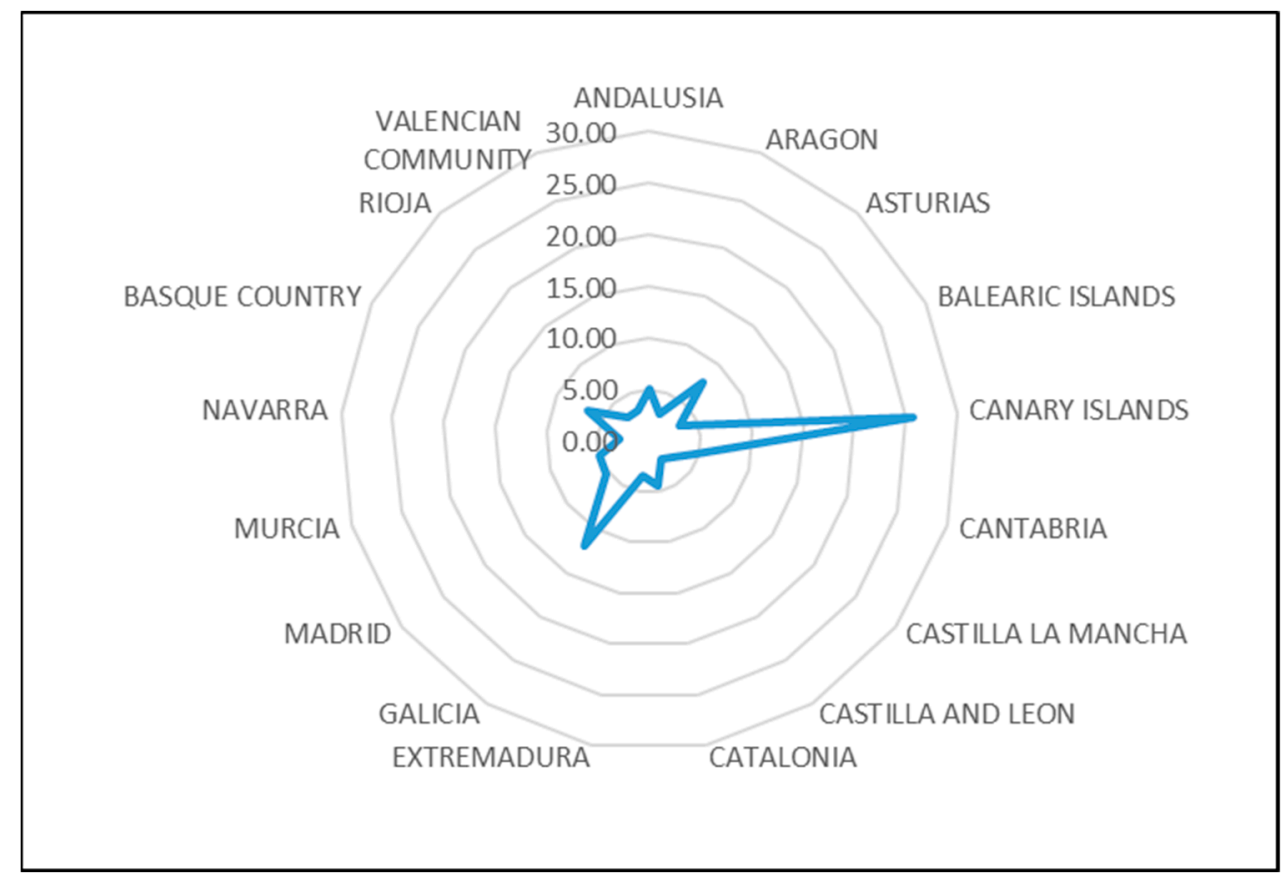

Figure 1. Distribution of funds per hectare in Spain (Source: Own elaboration from data published by the Ministry of Agriculture, Fisheries, and Food).

In addition, there is a commitment to co-financing by the member states. Specifically, for this type of fund, it ranges between $53 \%$ and $85 \%$.

In recent decades, two packages of funds have been approved: one for the period 2007 to 2013 and another for 2014 to 2020. In the latter, $€ 99,586,451,994$ were allocated to finance agricultural projects, of which $€ 8,297,388,821$ corresponded to Spain. Subsequently, and taking into account the high degree of territorial decentralisation of the country, these resources are distributed among the Spanish regions that have their own competences both in agrarian matters, as well as in the management, application, and justification of the European Funds. The Common Agricultural Policy Reform of 2013 introduced a new basic payment scheme for farmers, which was also applied in the eighteen member states. The Basic Payment Scheme is intended to provide basic income support for farmers and, thus, contribute to the viable production of food in the EU without distorting production decisions. Among all the direct payments received by farmers in the EU, through the different financial mechanisms of the Common Agricultural Policy, the most important of them all is the Basic Payment Scheme [6]. 
Table 1 presents the distribution of the EAGF and EAFRD funds in the 17 Spanish regions.

Table 1. Distribution of EAFRD and EAGF funds in Spanish regions (Source: Own elaboration from data published by the Ministry of Agriculture, Fisheries, and Food).

\begin{tabular}{ccccc}
\hline & \multicolumn{2}{c}{ EAFRD } & \multicolumn{2}{c}{ EAGF } \\
\hline & $\mathbf{2 0 0 7 - 2 0 1 3}$ & $\mathbf{2 0 1 4 - 2 0 1 9}$ & $\mathbf{2 0 0 7 - 2 0 1 3}$ & $\mathbf{2 0 1 4 - 2 0 1 9}$ \\
ANDALUSIA & $1,152,232,636$ & $1,019,670,477$ & $9,654,187$ & $1,316,063,405$ \\
ARAGON & $322,474,820$ & $272,145,901$ & $2,371,820$ & $388,613,223$ \\
ASTURIAS & $261,094,682$ & $126,472,228$ & 268,800 & $38,385,231$ \\
BALEARIC ISLANDS & $25,891,937$ & $40,604,327$ & 130,551 & $22,945,046$ \\
CANARY ISLANDS & $83,826,028$ & $118,171,711$ & 0 & 0 \\
CANTABRIA & $60,240,311$ & $69,101,404$ & 200,061 & $28,077,314$ \\
CASTILLA LA MANCHA & $633,146,804$ & $472,011,313$ & $3,815,654$ & $569,248,532$ \\
CASTILLA AND LEON & $600,863,526$ & $440,863,820$ & $4,988,589$ & $757,798,249$ \\
CATALONIA & $205,692,169$ & $346,303,958$ & $1,682,845$ & $235,689,789$ \\
EXTREMADURA & $428,840,620$ & $451,725,588$ & $2,591,770$ & $430,539,688$ \\
GALICIA & $525,796,704$ & $528,762,573$ & 751,164 & $115,706,304$ \\
MADRID & $36,793,820$ & $176,559,816$ & 232,953 & $34,939,920$ \\
MURCIA & $124,568,812$ & $121,375,325$ & 317,245 & $49,433,489$ \\
NAVARRE & $107,937,680$ & $56,150,828$ & 556,716 & $89,396,872$ \\
BASQUE COUNTRY & $56,541,728$ & $96,281,045$ & 256,945 & $32,922,788$ \\
RIOJA & $41,733,287$ & $42,010,323$ & 162,287 & $23,850,492$ \\
VALENCIAN COMMUNITY & $100,574,116$ & $105,574,845$ & 601,403 & $97,172,557$ \\
\hline
\end{tabular}

The distribution criteria were adopted at the Sectoral Conference, held on 21 January 2014. Funds are distributed according to the economic, environmental, and territorial indicators related to the three objectives of the rural development policy. These objectives include competitiveness of agriculture, sustainable management of natural resources and climate action, and balanced territorial development. These objectives can be verified by applying the formula of the "integration hypothesis" of the CAP reform contained in the commission's working documents for the distribution of rural development funds among member states.

Based on this process of distribution of European funds among the Spanish regions, the objective of this research is to determine whether there is a high degree of homogeneity in the levels of efficiency achieved by agricultural projects financed by these European resources in the development of the sector. In this way, it would be possible to identify which are the regions with the highest levels of efficiency in the management of agricultural projects approved and financed with European funds. Thus, once these territorial differences have been detected, the investigation could be expanded to find out which are the programs that have been implemented in the regions and which are the best results obtained.

In addition, the results can be used for public administrations to develop regulations, within their powers, that incorporate the degree of efficiency achieved, as another weighting parameter in the approval of projects financed with European Funds. Likewise, the active persons, who are those who present the projects, could access a national and territorial database created for this purpose. This database could allow knowing the peculiarities of the projects with the best qualification and the regions in which they have been implanted.

This type of analysis requires the use a methodology usually carried out by researchers when studying efficiency analyses. In this research, a non-parametric methodology called data envelopment analysis (DEA), proposed by Charnes, Cooper, and Rhodes in 1978, has been used.

This manuscript is structured as follows. After this introduction, the distribution of the European Agricultural Guarantee Fund (EAGF) and the European Agricultural Fund for Rural Development (EAFRD) among the different regions are analysed. Subsequently, a literature review is presented by collecting main contributions in the field of efficiency 
analysis of the agricultural sector. Then, the DEA model used is presented and the input/output variables used in the production function are defined. In the fourth section, the methodology is applied and, based on the results obtained, the conclusions and discussion proposals are presented.

\section{The Agricultural Funds}

\subsection{The European Agricultural Fund for Rural Development}

The European Agricultural Fund for Rural Development (EAFRD) is described in Regulation (EU) No. 1305/2013. This fund contributes to the Europe 2020 Strategy by creating a sustainable rural area throughout the EU. To this end, it finances projects related to the development of the European agricultural sector, which is linked to the creation of an increasingly balanced territorial and environmental system, respecting the climate issues as well as competitiveness and innovativeness.

In its development, this regulation proposes the long-term achievement of three basic goals: the promotion of agricultural competitiveness, the sustainable management of natural resources and action against the climate, and the achievement of a balanced territorial development with creation and maintenance of employment.

In recent decades, two packages of funds have been approved: one for the period 2007 to 2013 and another for the period 2014 to 2020. Figures 2 and 3 show the distribution of such funds among the different Spanish regions.

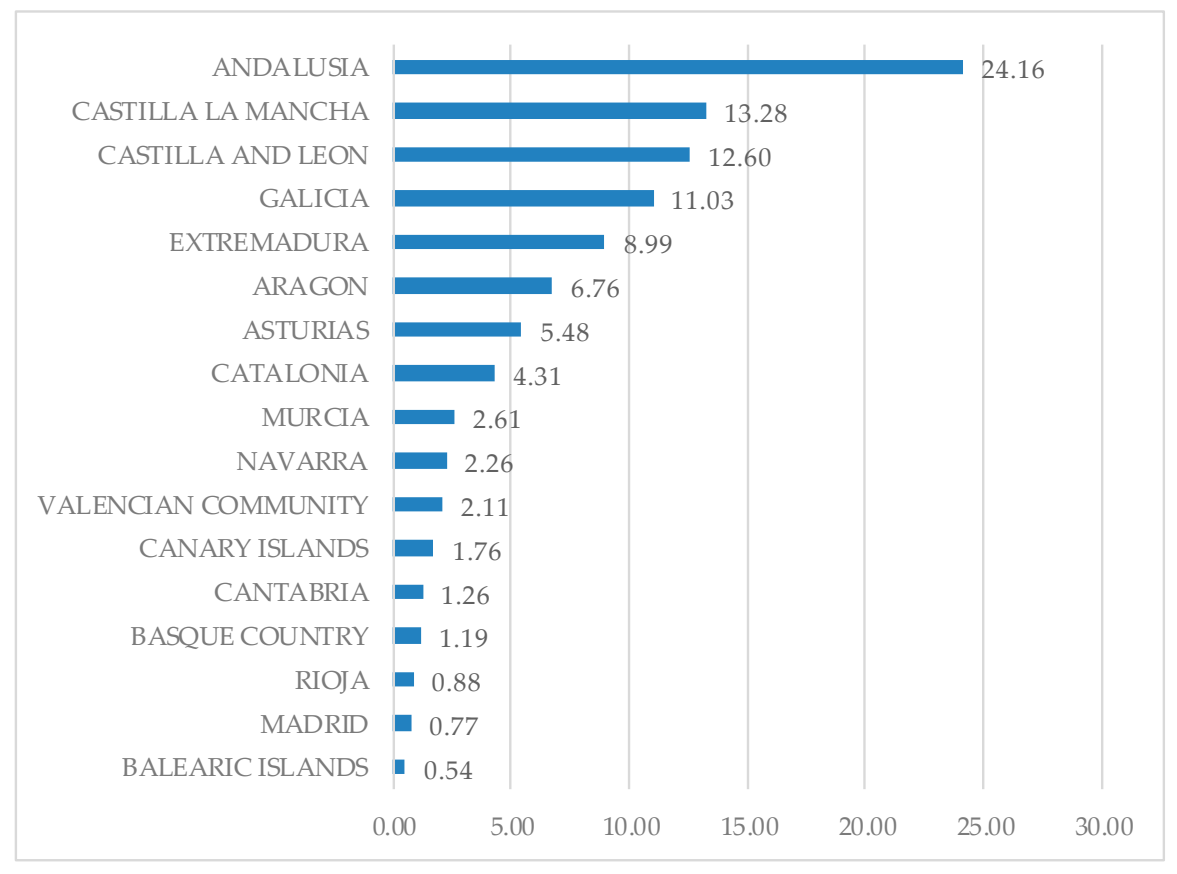

Figure 2. EAFRD percentage distribution for the period 2007-2013 (Source: Own elaboration from data published by the Ministry of Agriculture, Fisheries, and Food). 


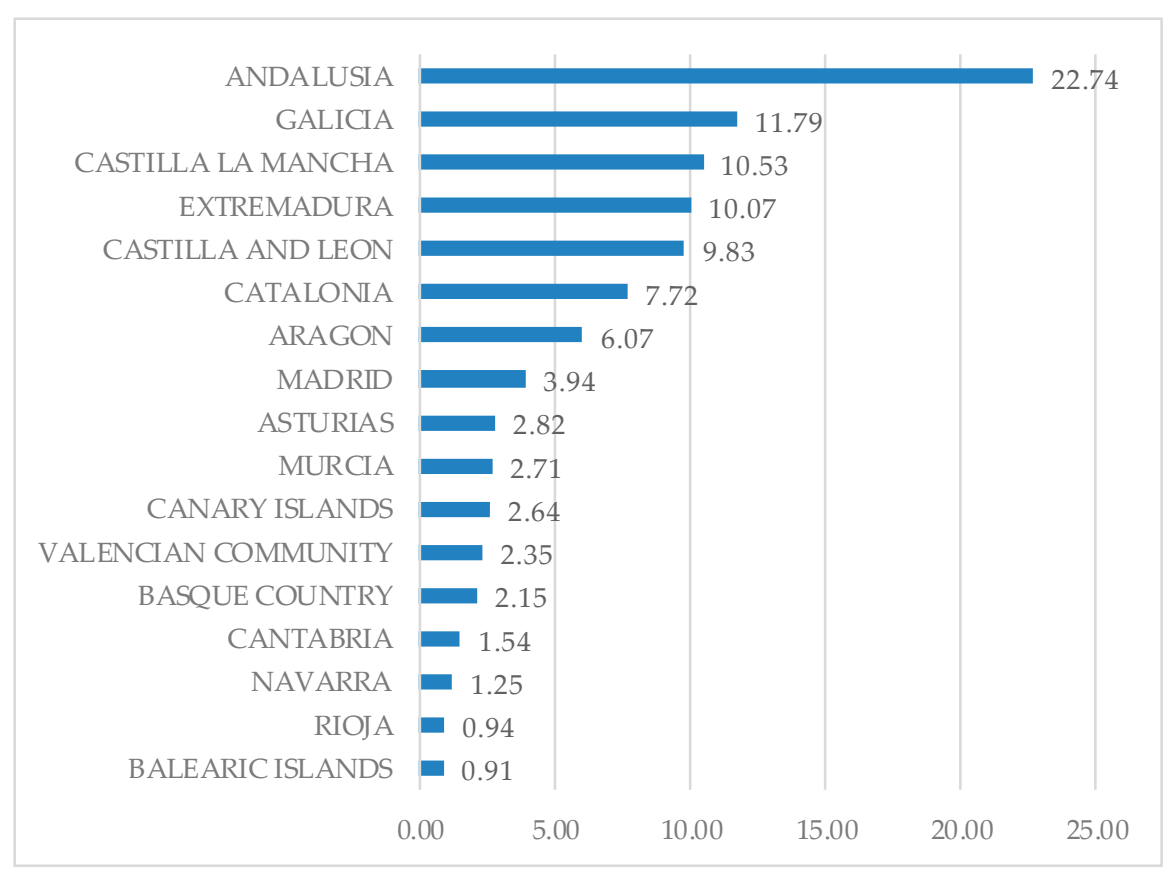

Figure 3. Percentage distribution of the EAFRD for the period 2014-2020 (Source: Own elaboration from data published by the Ministry of Agriculture, Fisheries and Food).

Figure 2 shows how almost $70 \%$ of these funds are concentrated in five regions: Andalusia, Castilla La Mancha, Castilla and Leon, Galicia, and Extremadura. In all of them, the agricultural sector plays an important role in generating its regional GDP.

Figure 3 shows the percentage distribution for the period 2014-2020. On this occasion, the five regions above continue to occupy the top positions, with the highest amount of funds received, but to a lesser extent. In fact, among them, they receive $64 \%$ of the total from the said funds. It should also be noted how the regions of Aragon, Cantabria, and Extremadura increased European resources by almost one percentage point if compared to the previous period.

\subsection{The European Agricultural Guarantee Fund}

The EAGF is regulated, among others, by Regulation (EU) No. 1306/2013. It is intended to finance measures aimed at regulating or supporting agricultural markets, direct payments to farmers under the CAP, and information and promotion measures for agricultural products in the internal EU market and in third countries. Figures 3 and 4 show the distribution made by region from such funds. As in the previous Figures 1 and 2, two study periods have been divided: one corresponding to the years 2007 to 2013 and the other covering between the years 2014 and 2020.

For the first period (Figure 4), it is observed that more than $81 \%$ of these resources were directed to the regions of Andalusia, Castilla and Leon, Castilla La Mancha, Extremadura, and Aragon. In this case, it is observed that four of the regions that are receiving the greatest amount of EAFRD coincide.

In the following period of 2014-2020 (Figure 5), this percentage is maintained. It should be noted how Andalusia lost more than two percentage points, while Extremadura and Aragon increased their contribution by almost one percentage point each in relation to the previous period. 


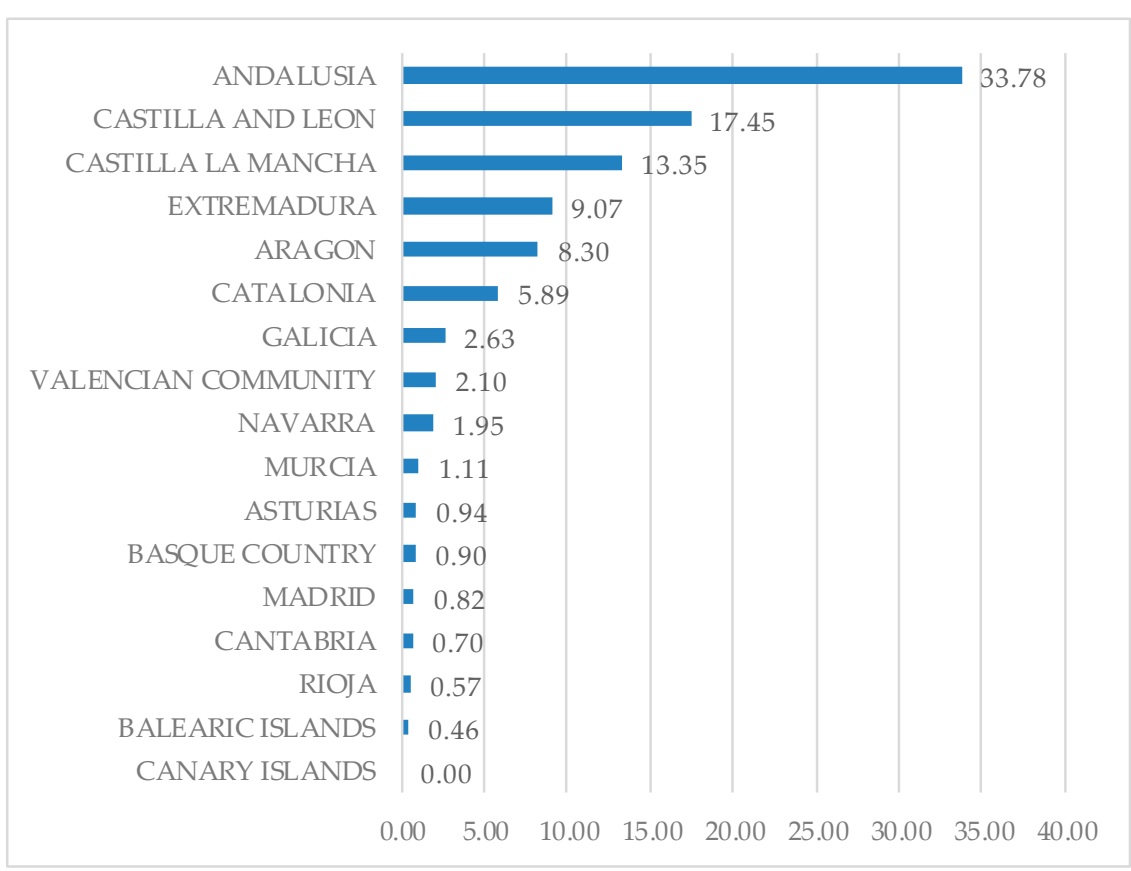

Figure 4. Percentage distribution of the EAGF for the period 2007-2013 (Source: Own elaboration from data published by the Ministry of Agriculture, Fisheries and Food).

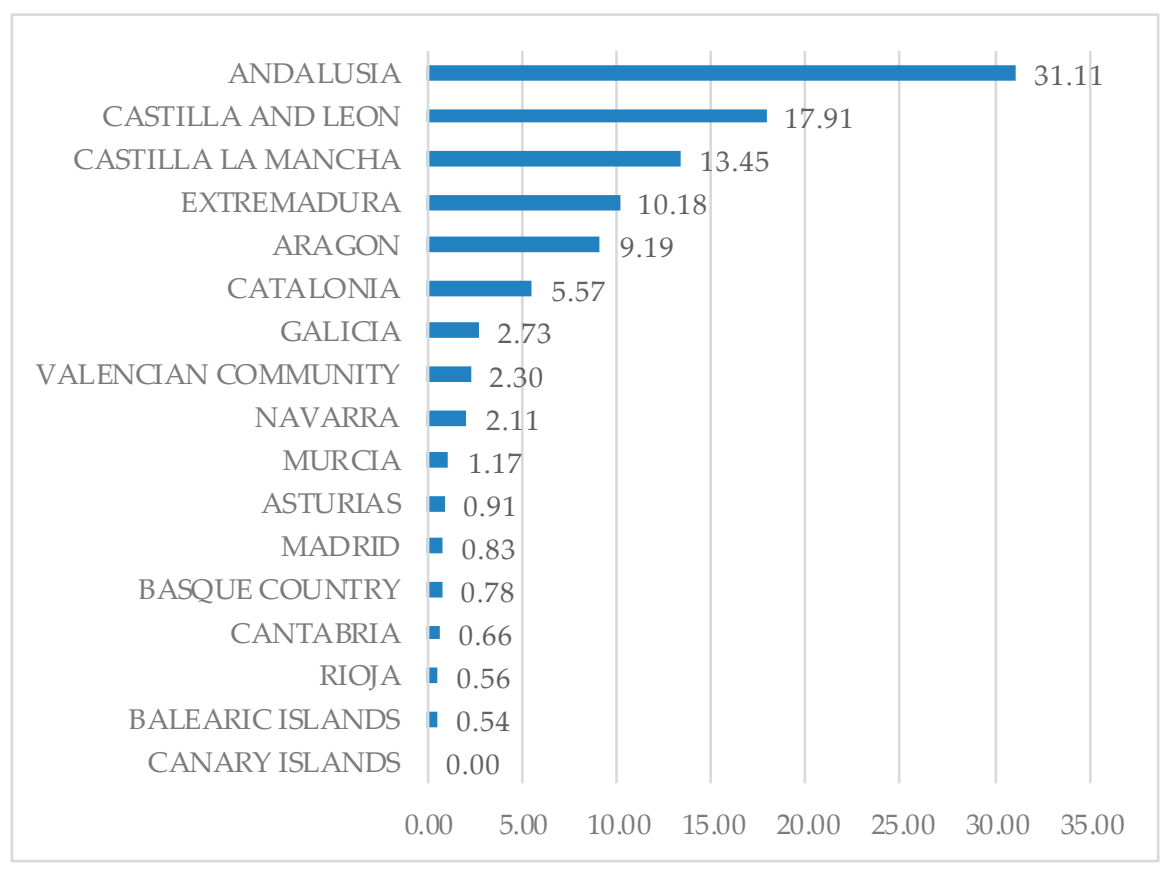

Figure 5. Percentage distribution of the EAGF for the period 2014-2020 (Source: Own elaboration from data published by the Ministry of Agriculture, Fisheries and Food).

\section{Methodology}

There are several studies that performed analysis of efficiency in agriculture [7-16]. Among the consulted studies, the traditional conception of the economic efficiency concept is assumed, such as the ability of organisations to produce the maximum number of useful products with a certain number of inputs, or the ability to produce a certain number of products, using for this the minimum possible inputs [17]. 
Once the central theme of this article had been conceptualised, a bibliographic search was carried out among the main scientific databases to determine a methodology that had been frequently used by different authors to measure efficiency in the agricultural sector, in a territorial approach. It was possible to verify the existence of numerous studies that use the so-called border model in their analysis. This model describes a production function whose components can be defined by using parametric or non-parametric techniques. For this function, the maximum-production frontier is calculated, which determines the greatest quantity of product that can be obtained from a certain combination of inputs [18].

Once the maximum production curve is known, different production units can be compared, measuring the distance at which they are with respect to that point that maximises production. In this way, comparative efficiency analyses can be carried out between different decision-making units, which are also known as DMUs [19].

Subsequently, a new bibliographic search was carried out to determine parametric or non-parametric models for determining efficiency levels. The result of these investigations has made it possible to determine how the non-parametric DEA methodology is a research instrument widely used today, and that it is frequently applied to various sectors of the economy [20]. In the specific field of the agrarian economy, the contributions of Karimov [21], Niavis et al. [22], Jalilov et al. [23], Arru et al. [24], Sintori, Liontakis, and Tzouramani [25], Mengui, Oh, and Lee [26], Havlíček et al. [27], Gołaś et al. [28], FernándezUclés et al. [29], Işgın et al. [30], and Bahta, Jordaan, and Sabastain [31] were identified.

Karimov [21] applied a non-parametric efficiency analysis for analysing crop production in Uzbekistan. By using the DEA, the author studied farms located in two regions of this country. Among main findings, the study revealed a need to extend the efficient use of resources studies. Although the farmers proved to be scale-efficient, they were not productively efficient. Moreover, the DEA model showed several indexes that contribute to production efficiency, such as soil fertility, farm size, water availability, crop diversification, dependency ratio, potential to work in a large land area, and longer distance to market.

The study of Niavis et al. [22] covered efficiency rates of Greek agricultural holdings. Using the same DEA methodology, the authors revealed that further studies are needed for restructuring the production process to improve efficiency and decreasing production costs of inefficient farmers. Additionally, Jalilov et al. [23] focused the resource use efficiency in rice farms of Bangladesh. The DEA methodology was also applied and revealed that $83 \%$ of farms proved to be efficient, being located on an efficiency frontier, and $2 \%$ of them were inefficient. This study allowed suggestions in order to improve their efficiency.

Another study that applied the DEA methodology was that of Arru et al. [24] when investigating the technical efficiency of agritourism in Sardinia. Data revealed that the efficiency can be improved if technical inputs are adequately used. Then, the improvements of the efficiency are more needed in the recreational services subsector. In the study of Sintori, Liontakis, and Tzouramani [25], the management practices that encourage the mitigation of greenhouse gas (GHG) emissions in the Greek rural economy were analysed. Data analysis was carried out with the aid of DEA methodology, revealing that the technical and environmental efficiency of sheep farms are tied. Among the factors that positively influence farms' efficiency are farm size, specialisation, and production orientation.

Mengui, Oh, and Lee [26] stressed the technical efficiency of smallholder Irish potato producers. Analyses resulted from DEA methodology allowed the identification that to reduce the level of technical inefficiencies, training activities would improve agronomic knowledge for potato production. The study also showed suggestions for policies and programmes aiming at services improvements in the studied region. Another study carried out by Havlíček et al. [27] focussed the performance and ranking of pork producers in different countries. The same DEA methodology revealed that in the first round, Brazil, the USA, and the Netherlands showed the highest-ranking values, and that Belgium, Czech Republic, Denmark, Finland, Italy, Netherlands, and Spain were classified as efficient producers.

Gołaś et al. [28] also measured the eco-efficiency of Polish farms, according to the data available from the Polish Farm Accountancy Data Network (FADN). The applied DEA 
revealed that farms could reduce their inputs by almost one-quarter without reducing their outputs. The study of Fernández-Uclés et al. [29] related to the economic efficiency of Tunisian olive oil firms also focussed the efficiency analysis through DEA methodology. The main findings underlined that the factors that showed greater economic efficiency are those related greatly to information and communication technologies (ICT) factors.

The research of Işgin et al. [30] also used the DEA methodology to examine Harran Plain cotton farming in Turkey. Among the findings, the authors were able to determine the factors affecting technical efficiencies of such farms. Moreover, small-scale farmers were identified as more efficient if compared with medium- and large-scale farmers. In the study of Bahta, Jordaan, and Sabastain [31], the DEA was also used to identify factors affecting technical efficiency of smallholder maize farmers at Zimbabwe. The authors found that the mean technical efficiency was $77 \%$, indicating an efficiency increase of $30 \%$.

The DEA methodology proposed in this research is based on the model developed by Charnes, Cooper, and Rhodes [6], and it allows determining the relative efficiency of an organisation in relation to others and its distance with respect to the efficiency frontier [32].

In this model, an optimal level of efficiency is determined, and the distance that exists between each of the DMUs with respect to it is measured. For this reason, the production function must be oriented towards outputs. Likewise, as there is no certainty about the type of return of the function, a BCC-Output type model has been assumed, which yields a measure of pure technical efficiency, thus ignoring the size of the scale since it compares only one DMU to a similar scale unit [33].

The fact of being able to include multiple input and output variables in this model has made it an efficiency measurement tool usually used in the evaluation of public sector policies [34] since public organisations pursue multiple objectives, which makes it difficult to determine their performance levels [34,35].

For this, in this model, the efficiency of the decision-making unit (DMU) is obtained as:

$$
E f=\frac{\mathrm{Y}}{\mathrm{X}}=\frac{\text { OUTPUT }}{\text { INPUT }} \text {. }
$$

When more inputs are used, the equation would be as follows:

$$
E f=\frac{a_{i} Y_{i}}{b_{i} X_{i}}
$$

The applied model aims to achieve the maximum amount of output given a certain level of inputs under a restriction of ignorance of the technological level assumed by each DMU. For this reason, the variable scale returns model (VRS) proposed by Banker, Charles, and Cooper [36] is used, which is oriented towards the output (BBC-output model). Thus, the problem to solve would be the maximisation of the following expression:

$$
\operatorname{Max} y_{j}+\varepsilon\left(\sum_{k=1}^{s} h_{k}^{+}+\sum_{i=1}^{m} h_{i}^{-}\right)
$$

Subject to:

$\sum_{j=1}^{n} \lambda_{j} * x_{i j}=x_{i j}-h_{i}^{-}, \quad i=1, \ldots, m \sum_{j=1}^{n} \lambda_{j} * y_{k j}=y_{k j} * \gamma_{j}+h_{k}^{+}, \quad k=1, \ldots, m \sum_{j=1}^{n} \lambda_{j}=1 \quad \lambda_{j}, h_{i}^{-}, h_{k}^{+} \geq 0, \forall i, j, k \quad \gamma_{j}$ free where:

$\gamma_{j}$ is the radial enlargement that occurs in all its outputs. It can be identified with the efficiency of $j$ if $j$ is compared with a point belonging to the efficient frontier.

$h_{i}^{-}$is the rectangular reduction of input $i$.

$h_{k}^{+}$is the rectangular magnification of the output $k$. 
$\lambda_{j}$ represents the coefficients of the linear combination of inputs and outputs to which the DMU projection point is referring on the efficient frontier. It can be interpreted as the proximity of the DMU projection point, with respect to the efficient frontier.

In this way, the efficiency frontier would be made up of all those efficient decisionmaking units. Once the border has been determined by these entities, it compares each of the entities under study with the border, under the assumption that the detected deviations indicate inefficient behavior. In this way, the relative efficiency of a set of DMUs that produce a type of output from a common set of inputs can be measured.

From the analysis of the existing literature, the inputs and outputs applied to research on economic efficiency analysis in the agricultural sector are shown in Table 2.

Table 2. Input-output variables used by agricultural efficiency researchers (Source: Own elaboration).

\begin{tabular}{|c|c|c|}
\hline Reference & Output Variables & Input Variables \\
\hline Havlíček et al. [27] & $\begin{array}{l}\text { Carcass meat production in } \\
\text { sow } / \text { year } / \mathrm{kg}\end{array}$ & $\begin{array}{l}\text { Feed costs, other variable costs, labor costs, } \\
\text { depreciation and finance costs }\end{array}$ \\
\hline Gołaś et al. [28] & $\begin{array}{l}\text { Value of the farm's agricultural } \\
\text { production }\end{array}$ & $\begin{array}{l}\text { Utilised farm area in ha, number of work units, } \\
\text { value of assets (capital without land value), } \\
\text { value of indirect consumption, nitrogen } \\
\text { surpluses in } \mathrm{kg} \mathrm{N} \text { per farm, phosphorus } \\
\text { surpluses in kg P2O5 per farm }\end{array}$ \\
\hline Fernández-Uclés et al. [29] & Turnover & $\begin{array}{l}\text { Staff costs, expenditure on raw materials and } \\
\text { other materials, Depreciation of property, plant } \\
\text { and equipment }\end{array}$ \\
\hline Bahta, Jordaan, and Sabastain [31] & Maize output per hectare & Nitrogen, phosphorus, potassium, and labor \\
\hline Mengui, Oh, and Lee [26] & Potato quantity (bags of $100 \mathrm{~kg}$ ) & $\begin{array}{l}\text { Land size, seed quantity, potato labor used, } \\
\text { capital, fertiliser, pesticides }\end{array}$ \\
\hline Jalilov et al. [23] & $\begin{array}{l}\text { Total yield of the main product } \\
\text { (rice), yield of by-product (straw) }\end{array}$ & $\begin{array}{l}\text { Seed and seedlings cost, land preparation cost, } \\
\text { seedling transplanting cost, irrigation cost, } \\
\text { fertiliser cost, weed control cost, pest control } \\
\text { cost, crop harvest and carrying, threshing, } \\
\text { winnowing and drying cost }\end{array}$ \\
\hline Arru et al. [24] & $\begin{array}{l}\text { Farming production, Recreational } \\
\text { services }\end{array}$ & $\begin{array}{l}\text { Land area, labor, capital, variable costs, } \\
\text { provision of meals, accommodation }\end{array}$ \\
\hline Sintori, Liontakis, and Tzouramani [25] & Milk per ewe, Lamb per ewe & $\begin{array}{l}\text { Pastureland per productive ewe, labor per } \\
\text { productive ewe, feedstuff per productive ewe, } \\
\text { variable capital per productive ewe, ghg } \\
\text { emissions per ewe }\end{array}$ \\
\hline Niavis et al. [22] & $\begin{array}{l}\text { Olive oil quantities produced from } \\
\text { each farm, revenue achieved }\end{array}$ & $\begin{array}{l}\text { Acreage in Ha of each farm, annual costs of } \\
\text { energy, agrochemicals (fungicides and } \\
\text { pesticides), fertilisers, and labor }\end{array}$ \\
\hline Karimov [21] & $\begin{array}{l}\text { Quantities of production both sold } \\
\text { and kept for self-consumption }\end{array}$ & $\begin{array}{l}\text { Land, labor, seeds, nitrogen fertiliser, diesel } \\
\text { and other expenses }\end{array}$ \\
\hline
\end{tabular}

As can be seen, the studies that used the European funds as an input variable in the agrarian sector are scarce. However, it is used to measure the efficiency in the use of public resources is quite common in other sectors [37,38]. Thus, Pérez, Blanco and Sánchez [39], and Blanco [40] applied it to determine the efficiency of employment programmes in the regions of Andalusia, Blanco et al. [37] applied it in the field of gender equality policies, and Ferasso, Blanco, and Bares [38] applied it in the renewable energy sector. Thus, the greatest novelty of this research presents with respect to those published is precisely the use of a variable that collects the public resources used to boost the sector.

For this reason, in this research, the EAFRD and the EAGF funds, used in Spain at the regional level, have been considered as input variables. Likewise, regarding the output variables, the regional agrarian GDP, the Gross Capital Formation of the primary sector, the total employment generated in it, and the remuneration generated have been chosen. In this way, the main variables used in the analysed bibliography are collected, which are related to the use of capital and employment. 
Table 3 summarises the input/output variables used in the production function to be maximised, and which will allow a comparative analysis of the relative efficiency of each DMU.

Likewise, Table 4 shows the analysed DMUs, as well as the level of development achieved in relation to the European average.

Figure 6 shows a summary of the methodology and variables used in this research.

Table 3. Production function of the degree of efficiency in the use of agricultural funds (Source: Own elaboration).

\begin{tabular}{|c|c|c|c|}
\hline Type of Variable & Variable & Description & Explication \\
\hline \multirow{4}{*}{$\begin{array}{l}\text { Product } \\
\text { (output) }\end{array}$} & O1ij: GDP & $\begin{array}{l}\text { GDP of the agricultural sector of the } \\
\text { regions where } i \text { is the region and } j \text { is } \\
\text { the year. }\end{array}$ & $\begin{array}{l}\text { Collects the total production of crops } \\
\text { generated in an economy during the } \\
\text { calendar year. }\end{array}$ \\
\hline & O2ij: Employment & $\begin{array}{l}\text { Total employment generated in the } \\
\text { agricultural sector in the regions } \\
\text { where } i \text { is the region and } \mathrm{j} \text { is the } \\
\text { year. }\end{array}$ & $\begin{array}{l}\text { Collects the total employment } \\
\text { generated in an economy in the } \\
\text { agricultural sector. }\end{array}$ \\
\hline & $\begin{array}{l}\text { O3ij: Gross Fixed Capital } \\
\text { Formation }\end{array}$ & $\begin{array}{l}\text { Gross Fixed Capital Formation used } \\
\text { in the agricultural sector where } i \text { is } \\
\text { the region and } j \text { is the year. }\end{array}$ & $\begin{array}{l}\text { Gross fixed capital formation is a } \\
\text { macroeconomic concept that measures } \\
\text { the value of fixed assets acquired or } \\
\text { produced in a given period by both the } \\
\text { public and private sectors. In this case, } \\
\text { it reflects the valuation of the Gross } \\
\text { Fixed Capital Formation (GFCF) of } \\
\text { agricultural products, integrated by the } \\
\text { GFCF of plantations and animals, and } \\
\text { of non-agricultural products, integrated } \\
\text { by the GFCF) of materials, machinery } \\
\text { and transportation, buildings and } \\
\text { others. }\end{array}$ \\
\hline & $\begin{array}{l}\text { O4ij: Employee } \\
\text { Remuneration }\end{array}$ & $\begin{array}{l}\text { Employee remuneration of the } \\
\text { agricultural sector where } \mathrm{i} \text { is the } \\
\text { region and } \mathrm{j} \text { is the year. }\end{array}$ & $\begin{array}{l}\text { Refers to the gross income of the } \\
\text { worker and the supplements received } \\
\text { in kind valued in euros from the } \\
\text { agricultural sector. }\end{array}$ \\
\hline $\begin{array}{l}\text { Supplies } \\
\text { (Inputs) }\end{array}$ & I2ij: EAFRD & $\begin{array}{l}\text { Annual investment of the region in } \\
\text { EAGF, where } i \text { is the region and } j \text { is } \\
\text { the year. } \\
\text { Annual investment of the region in } \\
\text { EAFRD, where } i \text { is the region and } j \\
\text { is the year. }\end{array}$ & \\
\hline
\end{tabular}


Table 4. DMUs used and level of development (Source: European Commission).

\begin{tabular}{|c|c|c|}
\hline Development Levels & Description & DMUs \\
\hline Less developed regions & $\begin{array}{l}\text { Regions whose gross domestic product (GDP) per } \\
\text { capita is less than } 75 \% \text { of the average GDP of the } \\
\text { EU- } 27 .\end{array}$ & Extremadura \\
\hline Regions in transition & $\begin{array}{l}\text { Regions whose GDP per capita is between } 75 \% \\
\text { and } 90 \% \text { of the average GDP of the EU- } 27 \text {. }\end{array}$ & $\begin{array}{l}\text { Castilla La Mancha } \\
\text { Andalusia } \\
\text { Murcia } \\
\text { Canary Islands }\end{array}$ \\
\hline More developed regions & $\begin{array}{l}\text { Regions whose GDP per capita is above } 90 \% \text { of the } \\
\text { average GDP of the EU- } 27 \text {. }\end{array}$ & $\begin{array}{c}\text { Galicia } \\
\text { Asturias } \\
\text { Cantabria } \\
\text { Basque Country } \\
\text { Navarra } \\
\text { Rioja } \\
\text { Aragon } \\
\text { Madrid } \\
\text { Castilla and Leon } \\
\text { Catalonia } \\
\text { Valencian Community } \\
\text { Balearic Islands }\end{array}$ \\
\hline
\end{tabular}

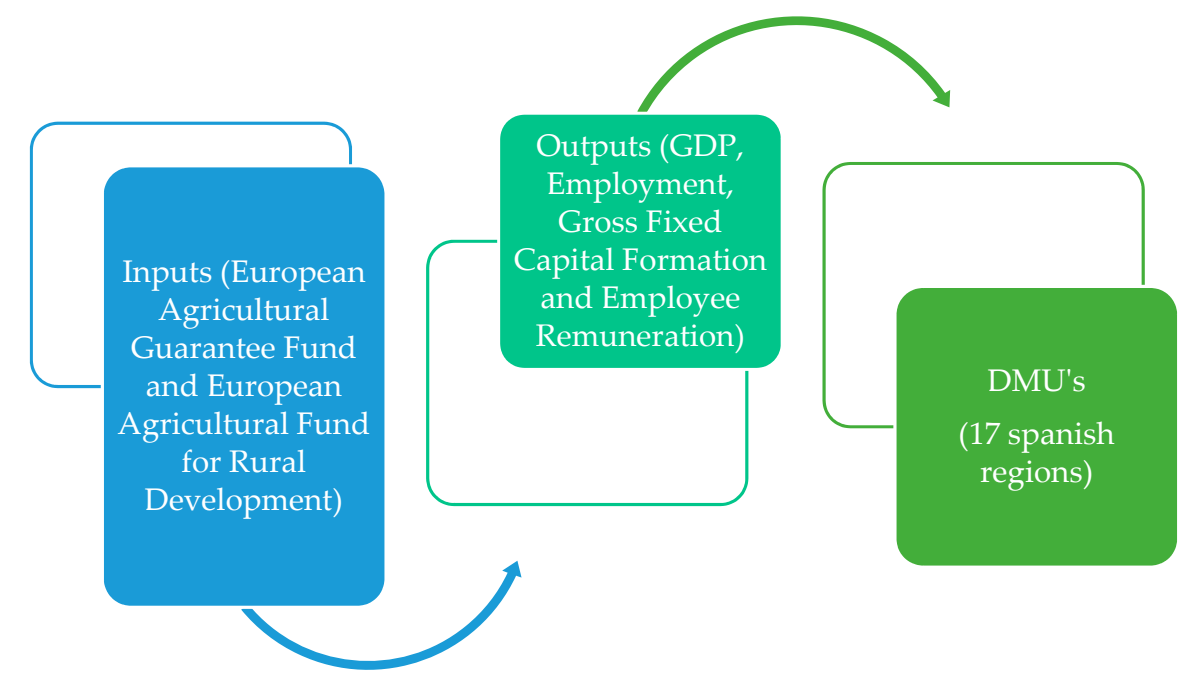

Figure 6. Summary of the applied methodology (Source: Authors' own elaboration).

\section{Results}

The efficiency analysis in the use of the European agricultural funds for the purpose of improving the sector has been carried out through a production function where the inputs would be formed by the investments in the EAGF and EAFRD. The outputs would be formed by the regional GDP, the total employment generated in the sector, the Gross Capital Formation, and the remuneration. The DMUs used are the Spanish regions. A DEA has been applied to this function that assumes an orientation towards output (BCC) and variable returns to scale. The software used was Frontier Analysis Professional.

The following tables show the obtained results. The relative efficiency has been calculated for the years corresponding to the two sub-periods of funds approved by the EU. The first covers the years 2007 to 2013 and the second covers the years 2014 to 2019. Although the period ranges from the years 2014 to 2020, 2019 is the last year in which there are results published by the European Commission. 
As can be seen in Table 5, there are significant differences during the analysed period. It should be noted that Andalusia, Murcia, the Valencian Community, Catalonia, the Canary Islands, Castilla La Mancha, Castilla and Leon, and Galicia are above the Spanish average. However, the regions of Aragon, La Rioja, the Balearic Islands, the Basque Country, Madrid, Extremadura, Navarra, Cantabria, and Asturias have obtained levels of efficiency below the average.

Table 5. Relative efficiency by regions for the period of 2007-2013 (Source: Own elaboration).

\begin{tabular}{|c|c|c|c|c|c|c|c|c|}
\hline DMUs & 2007 & 2008 & 2009 & 2010 & 2011 & 2012 & 2013 & AVERAGE \\
\hline ANDALUSIA & 100.00 & 100.00 & 100.00 & 100.00 & 100.00 & 100.00 & 100.00 & 100.00 \\
\hline ARAGON & 39.10 & 35.63 & 49.95 & 67.20 & 72.12 & 72.77 & 81.87 & 59.81 \\
\hline ASTURIAS & 20.59 & 11.78 & 14.47 & 19.38 & 15.45 & 15.96 & 23.74 & 17.34 \\
\hline BALEARIC ISLANDS & 31.39 & 20.05 & 100.00 & 100.00 & 100.00 & 11.27 & 31.62 & 56.33 \\
\hline VALENCIAN COMMUNITY & 78.93 & 100.00 & 100.00 & 100.00 & 100.00 & 100.00 & 100.00 & 96.99 \\
\hline CANARY ISLANDS & 100.00 & 100.00 & 100.00 & 100.00 & 47.79 & 44.39 & 40.28 & 76.07 \\
\hline CANTABRIA & 6.51 & 12.99 & 25.47 & 22.70 & 30.23 & 11.50 & 37.06 & 20.92 \\
\hline CASTILLA AND LEON & 40.81 & 62.54 & 56.00 & 79.12 & 89.31 & 88.35 & 93.42 & 72.79 \\
\hline CASTILLA LA MANCHA & 95.61 & 48.17 & 52.60 & 54.76 & 86.09 & 92.11 & 96.07 & 75.06 \\
\hline CATALONIA & 42.91 & 68.34 & 92.55 & 89.00 & 100.00 & 84.33 & 88.73 & 80.84 \\
\hline ESTREMADURA & 44.58 & 29.77 & 26.24 & 33.30 & 35.90 & 29.54 & 37.80 & 33.88 \\
\hline GALICIA & 100.00 & 63.10 & 51.97 & 51.65 & 71.81 & 64.45 & 82.00 & 69.28 \\
\hline RIOJA & 53.35 & 22.93 & 56.51 & 71.06 & 75.43 & 18.30 & 100.00 & 56.80 \\
\hline MADRID & 23.85 & 68.19 & 68.18 & 26.74 & 58.58 & 23.13 & 86.68 & 50.76 \\
\hline MURCIA & 100.00 & 100.00 & 100.00 & 100.00 & 100.00 & 100.00 & 100.00 & 100.00 \\
\hline NAVARRE & 13.07 & 23.01 & 36.00 & 28.71 & 42.58 & 24.87 & 33.83 & 28.87 \\
\hline BASQUE COUNTRY & 26.71 & 33.37 & 100.00 & 62.74 & 100.00 & 25.57 & 36.61 & 55.00 \\
\hline SPANISH AVERAGE & 53.97 & 52.93 & 66.47 & 65.08 & 72.08 & 53.33 & 68.81 & 61.81 \\
\hline
\end{tabular}

On the one hand, it is noticed how Andalusia and Murcia are placed on the frontier of efficiency, since they obtained values of 100 . Both regions have a long tradition of development of the agricultural sector throughout their history [41]. Andalusia had received in this period $24.16 \%$ of the EAFRD funds and 33.78\% of the EAGF. Murcia received $2.61 \%$ of the EAFRD and $1.11 \%$ of the EAGF. Thus, the high degree of efficiency in the management of the European Funds carried out by these regions is very positive. The difference in the percentage of funds received is conditioned by the regulations by the distribution system approved in the Sectorial Conference held on January 21, 2014. From a physical point of view, Andalusia is the second region in number of cultivated hectares-3.55 millions, while the Murcia region dedicates 477,571 hectares to cultivation.

On the opposite side are Navarra, Cantabria, and Asturias, which are regions that have obtained the lowest levels of efficiency during the period 2007 to 2013. Extremadura deserves special mention. This region received $8.99 \%$ of the EAFRD and $9.07 \%$ of the EAGF. However, the efficiency of its agricultural projects is below the Spanish average. (33.78).

Table 6 shows how, in the studied period, Andalusia, Murcia, Castilla La Mancha, Valencian Community, Galicia, Catalonia, Castilla and Leon, and the Canary Islands are above the Spanish average. On the opposite side are Navarre, Aragon, Rioja, Madrid, Extremadura, Basque Country, Balearic Islands, Asturias, and Cantabria. As in the previous period, the regions of Andalusia and Murcia are on the frontier of efficiency (100). Therefore, the relative positions above the national average and below remain intact. It should also be noted how Extremadura improved its relative position by almost 13 points, in addition to seeing how the EAFRD and EAGF resources received in this period increased. 
Table 6. Relative efficiency by regions for the period of 2014-2019 (Source: Own elaboration).

\begin{tabular}{cccccccc}
\hline DMUs & $\mathbf{2 0 1 4}$ & $\mathbf{2 0 1 5}$ & $\mathbf{2 0 1 6}$ & $\mathbf{2 0 1 7}$ & $\mathbf{2 0 1 8}$ & $\mathbf{2 0 1 9}$ & AVERAGE \\
\hline ANDALUSIA & 100.00 & 100.00 & 100.00 & 100.00 & 100.00 & 100.00 & 100.00 \\
ARAGON & 73.99 & 38.04 & 79.31 & 56.63 & 59.53 & 43.66 & 58.53 \\
ASTURIAS & 32.38 & 6.94 & 22.58 & 18.45 & 29.77 & 15.79 & 20.99 \\
BALEARIC ISLANDS & 52.35 & 12.01 & 10.90 & 19.64 & 38.18 & 10.47 & 23.93 \\
VALENCIAN COMMUNITY & 100.00 & 41.55 & 100.00 & 100.00 & 100.00 & 74.82 & 86.06 \\
CANARY ISLANDS & 44.97 & 100.00 & 32.65 & 67.52 & 100.00 & 26.91 & 62.01 \\
CANTABRIA & 32.91 & 4.40 & 17.32 & 13.32 & 48.30 & 9.27 & 20.92 \\
CASTILLA AND LEON & 100.00 & 52.52 & 87.76 & 62.13 & 60.83 & 57.54 & 70.13 \\
CASTILLA LA MANCHA & 73.30 & 100.00 & 100.00 & 100.00 & 100.00 & 100.00 & 95.55 \\
CATALONIA & 85.10 & 57.41 & 97.28 & 68.35 & 77.32 & 38.93 & 70.73 \\
ESTREMADURA & 29.96 & 46.66 & 47.49 & 55.83 & 54.69 & 49.33 & 47.33 \\
GALICIA & 72.38 & 100.00 & 67.94 & 41.22 & 97.77 & 48.87 & 71.36 \\
RIOJA & 71.67 & 32.13 & 100.00 & 32.12 & 81.91 & 19.06 & 56.15 \\
MADRID & 100.00 & 13.01 & 8.29 & 100.00 & 65.91 & 6.24 & 48.91 \\
MURCIA & 100.00 & 100.00 & 100.00 & 100.00 & 100.00 & 100.00 & 100.00 \\
NAVARRE & 100.00 & 100.00 & 68.71 & 33.80 & 32.41 & 20.38 & 59.22 \\
BASQUE COUNTRY & 74.38 & 28.07 & 21.85 & 22.12 & 63.38 & 15.97 & 37.63 \\
SPANISH AVERAGE & 73.14 & 54.87 & 62.48 & 58.30 & 71.18 & 43.37 & 60.55 \\
\hline
\end{tabular}

Tables 7 and 8 summarise the average efficiency of the regions during the two periods, the number of times each region has been found at maximum efficiency, the maximum and minimum efficiency, as well as the difference between both.

From the comparison of Tables 7 and 8, it is evident how the efficiency of the programs has been decreasing from one period to another. Thus, the Spanish average of efficiency for the period 2007-2013 was 61.81; however, we observed a decrease of 3.44 points for the next period. Andalusia and Murcia did not present any variation of efficiency. In the period 2007-2013 (Table 7), the regions with the highest decrease were the Balearic Islands, Rioja, and Basque Country. However, for the period 2014-2019, Madrid, Rioja, and Navarre presented the top lowering (Table 8). Finally, Figure 7 shows the variations of the efficiency levels in the period 2007-2019.

Table 7. Summary of efficiency indicators for the period of 2007-2013 (Source: Own elaboration).

\begin{tabular}{|c|c|c|c|c|c|}
\hline DMUs & AVERAGE & $\begin{array}{l}\text { N. OF TIMES OF } \\
\text { MAXIMUM } \\
\text { EFFICIENCY }\end{array}$ & $\begin{array}{l}\text { MAXIMUM } \\
\text { EFFICIENCY }\end{array}$ & $\begin{array}{l}\text { MINIMUM } \\
\text { EFFICIENCY }\end{array}$ & VARIATION \\
\hline ANDALUSIA & 100.00 & 7 & 100.00 & 100.00 & 0.00 \\
\hline ARAGON & 59.81 & 0 & 81.87 & 35.63 & 46.24 \\
\hline ASTURIAS & 17.34 & 0 & 23.74 & 11.78 & 11.96 \\
\hline BALEARIC ISLANDS & 56.33 & 3 & 100.00 & 11.27 & 88.73 \\
\hline VALENCIAN COMMUNITY & 96.99 & 6 & 100.00 & 78.93 & 21.07 \\
\hline CANARY ISLANDS & 76.07 & 4 & 100.00 & 40.28 & 59.72 \\
\hline CANTABRIA & 20.92 & 0 & 37.06 & 6.51 & 30.55 \\
\hline CASTILLA AND LEON & 72.79 & 0 & 93.42 & 40.81 & 52.61 \\
\hline CASTILLA LA MANCHA & 75.06 & 0 & 96.07 & 48.17 & 47.90 \\
\hline CATALONIA & 80.84 & 1 & 100.00 & 42.91 & 57.09 \\
\hline ESTREMADURA & 33.88 & 0 & 44.58 & 26.24 & 18.34 \\
\hline GALICIA & 69.28 & 1 & 100.00 & 51.65 & 48.35 \\
\hline RIOJA & 56.80 & 1 & 100.00 & 18.30 & 81.70 \\
\hline MADRID & 50.76 & 0 & 86.68 & 23.13 & 63.55 \\
\hline MURCIA & 100.00 & 7 & 100.00 & 100.00 & 0.00 \\
\hline NAVARRE & 28.87 & 0 & 42.58 & 13.07 & 29.51 \\
\hline BASQUE COUNTRY & 55.00 & 2 & 100.00 & 25.57 & 74.43 \\
\hline SPANISH AVERAGE & 61.81 & 0 & 72.08 & 52.93 & 19.14 \\
\hline
\end{tabular}


Table 8. Summary of efficiency indicators for the period of 2014-2019 (Source: Own elaboration.).

\begin{tabular}{|c|c|c|c|c|c|}
\hline DMUs & AVERAGE & $\begin{array}{l}\text { N. OF TIMES OF } \\
\text { MAXIMUM } \\
\text { EFFICIENCY }\end{array}$ & $\begin{array}{l}\text { MAXIMUM } \\
\text { EFFICIENCY }\end{array}$ & $\begin{array}{l}\text { MINIMUM } \\
\text { EFFICIENCY }\end{array}$ & VARIATION \\
\hline ANDALUSIA & 100.00 & 6 & 100.00 & 100.00 & 0.00 \\
\hline ARAGON & 53.91 & 0 & 79.31 & 38.04 & 41.27 \\
\hline ASTURIAS & 22.18 & 0 & 32.38 & 6.94 & 25.44 \\
\hline BALEARIC ISLANDS & 24.19 & 0 & 52.35 & 10.47 & 41.88 \\
\hline VALENCIAN COMMUNITY & 86.96 & 4 & 100.00 & 41.55 & 58.45 \\
\hline CANARY ISLANDS & 62.97 & 2 & 100.00 & 26.91 & 73.09 \\
\hline CANTABRIA & 26.16 & 0 & 48.30 & 4.40 & 43.90 \\
\hline CASTILLA AND LEON & 62.83 & 1 & 100.00 & 52.52 & 47.48 \\
\hline CASTILLA LA MANCHA & 98.52 & 5 & 100.00 & 73.30 & 26.70 \\
\hline CATALONIA & 62.33 & 0 & 97.28 & 38.93 & 58.35 \\
\hline ESTREMADURA & 50.45 & 0 & 55.83 & 29.96 & 25.87 \\
\hline GALICIA & 72.67 & 1 & 100.00 & 41.22 & 58.78 \\
\hline RIOJA & 52.37 & 1 & 100.00 & 19.06 & 80.94 \\
\hline MADRID & 40.35 & 2 & 100.00 & 6.24 & 93.76 \\
\hline MURCIA & 100.00 & 6 & 100.00 & 100.00 & 0.00 \\
\hline NAVARRE & 37.34 & 2 & 100.00 & 20.38 & 79.62 \\
\hline BASQUE COUNTRY & 38.99 & 0 & 74.38 & 15.97 & 58.41 \\
\hline SPANISH AVERAGE & 58.37 & 0 & 73.14 & 43.37 & 29.77 \\
\hline
\end{tabular}

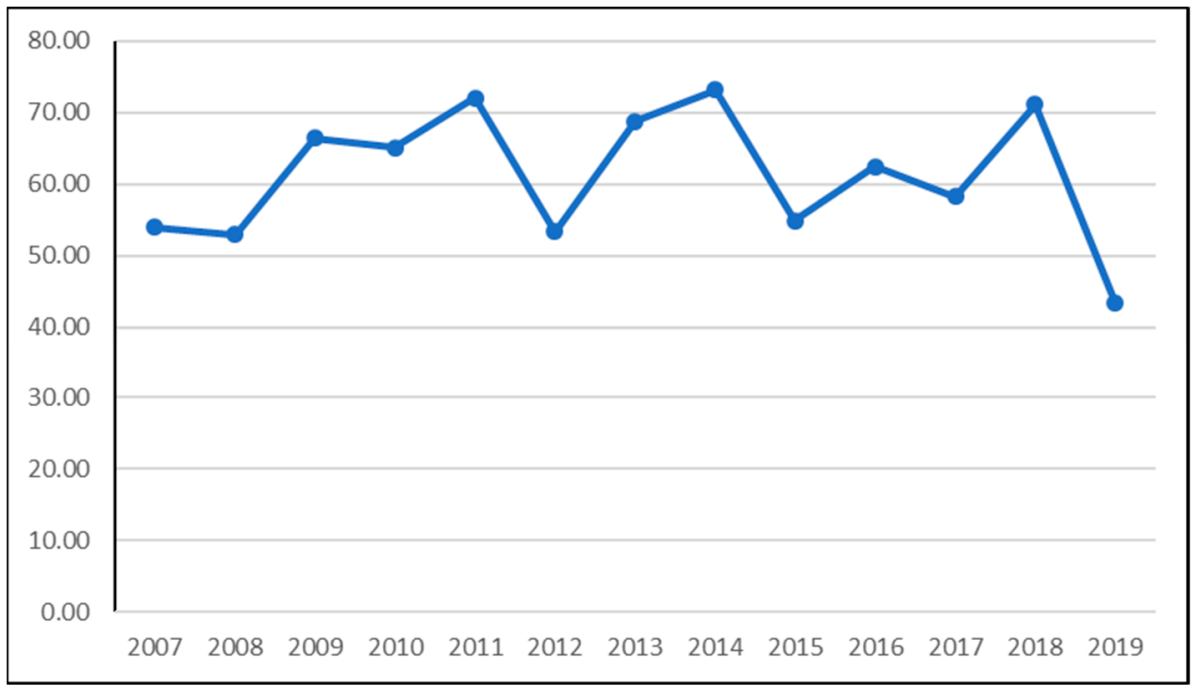

Figure 7. Evolution of the level of efficiency (Spanish average) period 2007-2019 (Source: Own elaboration).

\section{Discussion and Conclusions}

In this research, the goal was to determine whether there is a high degree of homogeneity in the levels of efficiency achieved by the Spanish regions in the management of agricultural projects financed by the EAFRD and EAGF. For this, we used a methodology frequently used by researchers in comparative efficiency analyses among various territorial units: data envelopment analysis. Thus, we defined a production function in which the inputs have been linked to the use of European funds and the outputs used were, in the agricultural sector, the regional GDP, the Gross Capital Formation, the total employment generated in the sector, and remuneration.

The application of the DEA revealed two main conclusions. On the one hand, there was the existence of a high degree of heterogeneity in the level of efficiency achieved by the Spanish regions during the two analysed periods. On the other hand, the average 
efficiency achieved during the period 2007 to 2013 was higher than that obtained in the following period.

These findings are in accordance with the results evidenced in the analysed bibliography. There is a high degree of correlation between efficiency levels and regional characteristics. In this sense, we considered this type of analysis very necessary, since it allows determining the existence of specific regional inequalities. In the current economic model, there is a natural tendency to create inequalities between territories, as has been evidenced in the consulted literature. Therefore, once identified, the results shown in this type of research can be used to articulate public policy measures aimed at reducing them. Since if resources are not allocated to reduce them, they will grow and perpetuate a project development with uneven regions. These models undoubtedly have negative consequences in different aspects of citizens' lives at the territorial level that is not only economic but also social. Therefore, in this research work, European funds (EAFRD and EAGF) have been included as an element to reduce regional differences in agricultural matters. Once identified, the results can be used to articulate public policy measures to reduce them, since in the event that no resources are allocated to reduce them, they will grow and perpetuate a development project with unequal regions. These models undoubtedly have negative consequences in different aspects of citizens' lives at territorial level not only in the economic dimension but also in social dimension.

In this research, we have identified two regions that were in the two periods located on the frontier of efficiency - that is, the regions of Andalusia and Murcia. With these results, we believe it is convenient to expand this study to identify the specific projects that have been launched during these years in these regions. Thus, they can be replicated in those that have obtained the lowest results.

We are currently in a moment of transition. The fund package for the period 2021 to 2027 has been approved on 17 December 2020. The total allocation for the CAP amounts to $€ 386.6$ billion. Of these, the EAGF has an endowment of $€ 291.100$ million and the EAFRD of more than $€ 94$ million. Around $30 \%$ of the recovery funds will be available in 2021, and the remaining $70 \%$ will be released in 2022. Therefore, it is advisable to highlight as soon as possible the projects that are working best at the agricultural level and publicise them so that they can be implemented in other regions.

Lastly, the efficiency analysis is conditioned by the input and output variables used. If the variables are changed, the production function defined in this manuscript is changed, and the data could be different. This is one of the great limitations of the study, although it is noticed not only in non-parametric models but in parametric ones.

Author Contributions: Conceptualisation, M.B. and L.B.; methodology, M.B.; software, M.B.; validation, M.B., M.F. and L.B.; formal analysis, M.B.; investigation, M.B. and L.B.; resources, M.B.; data curation, M.B.; writing-original draft preparation, M.B., M.F. and L.B.; writing—review and editing, M.B., M.F. and L.B.; visualisation, M.F.; supervision, M.F.; project administration, M.F. All authors have read and agreed to the published version of the manuscript.

Funding: This research received no external funding.

Institutional Review Board Statement: Not applicable.

Informed Consent Statement: Not applicable.

Conflicts of Interest: The authors declare no conflict of interest.

\section{References}

1. Fennell, R. The Common Agricultural Policy: Continuity and Change; Clarendon Press, Oxford University Press: Oxford, NY, USA, 1997.

2. Zobbe, H. The Economic and Historical Foundation of the Common Agricultural Policy in Europe; Institute of Food Economics, Unit of Economics, Royal Veterinary and Agricultural University: Frederiksberg, Denmark, 2001; pp. 1-20.

3. Saunders, C. EU Agenda: Reforming the CAP: A new agenda. N.Z. Int. Rev. 2000, 25, 24.

4. Cunha, A.; Swinbank, A. An Inside View of the CAP Reform Process; Oxford University Press: Oxford, NY, USA, 2011.

5. Matthews, A. Greening Agricultural Payments in the EU's Common Agricultural Policy. Bio-Based Appl. Econ. 2013,2 , 1-27. 
6. Leco, F.; Pérez, A. Desajustes territoriales en la distribución del Pago Básico de la PAC en España. Cuad. Geográficos 2019, 58, 57-82. [CrossRef]

7. Bravo-Ureta, B.E.; Pinheiro, A.E. Efficiency Analysis of Developing Country Agriculture: A Review of the Frontier Function Literature. Agric. Resour. Econ. Rev. 1993, 22, 88-101. [CrossRef]

8. Chavas, J.P.; Aliber, M. An analysis of economic efficiency in agriculture: A nonparametric approach. J. Agric. Resour. Econ. 1993, $18,16$.

9. Thiam, A.; Bravo-Ureta, B.E.; Rivas, T.E. Technical Efficiency in Developing Country Agriculture: A Meta-Analysis. Agric. Econ. 2001, 25, 235-243. [CrossRef]

10. Malá, Z. Efficiency analysis of Czech organic agriculture. E M Ekon. Manag. 2011, 1, 14-28.

11. Ndlovu, P.V.; Mazvimavi, K.; An, H.; Murendo, C. Productivity and Efficiency Analysis of Maize under Conservation Agriculture in Zimbabwe. Agric. Syst. 2014, 124, 21-31. [CrossRef]

12. Reith, C.C.; Guidry, M.J. Eco-Efficiency Analysis of an Agricultural Research Complex. J. Environ. Manage. 2003, 68, 219-229. [CrossRef]

13. Clark, M.; Tilman, D. Comparative analysis of environmental impacts of agricultural production systems, agricultural input efficiency, and food choice. Environ. Res. Lett. 2017, 12, 064016. [CrossRef]

14. Velasco-Muñoz, J.F.; Aznar-Sánchez, J.A.; Belmonte-Ureña, L.J.; López-Serrano, M.J. Advances in water use efficiency in agriculture: A bibliometric analysis. Water 2018, 10, 377. [CrossRef]

15. Mathijs, E.; Swinnen, J.F. Production organization and efficiency during transition: An empirical analysis of East German agriculture. Rev. Econ. Stat. 2001, 83, 100-107. [CrossRef]

16. Sanneh, N.; Moffitt, L.J.; Lass, D.A. Stochastic efficiency analysis of community-supported agriculture core management options. J. Agric. Resour. Econ. 2001, 26, 417-430.

17. Béraud, A. Jules Dupuit (1804-1866). In Handbook on the History of Economic Analysis Volume I; Faccarello, G., Kurz, H.D., Eds.; Chapter 28; Edward Elgar Publishing: Cheltenham, UK, 2016. [CrossRef]

18. Farrell, M.J. Measuring the Technical Efficiency. J. R. Stat. Soc. 1957, 120, 253-290.

19. Buchelli, G.A.; Marín Restrepo, J.J. Estimación de la eficiencia del sectormetalmecánico en colombia: Análisis de la frontera estocástica. Cuad. Econ. 2012, 31, 257-286.

20. Emrouznejad, A.; Yang, G.L. A survey and analysis of the first 40 years of scholarly literature in DEA: 1978-2016. Socio-Econ. Plan. Sci. 2018, 61, 4-8. [CrossRef]

21. Karimov, A. Productive Efficiency of Potato and Melon Growing Farms in Uzbekistan: A Two Stage Double Bootstrap Data Envelopment Analysis. Agriculture 2013, 3, 503-515. [CrossRef]

22. Niavis, S.; Tamvakis, N.; Manos, B.; Vlontzos, G. Assessing and Explaining the Efficiency of Extensive Olive Oil Farmers: The Case of Pelion Peninsula in Greece. Agriculture 2018, 8, 25. [CrossRef]

23. Jalilov, S.M.; Mainuddin, M.; Maniruzzaman, M.; Alam, M.; Islam, T.; Jahangir Kabir, M. Efficiency in the Rice Farming: Evidence from Northwest Bangladesh. Agriculture 2019, 9, 245. [CrossRef]

24. Arru, B.; Furesi, R.; Madau, F.; Pulina, P. Recreational Services Provision and Farm Diversification: A Technical Efficiency Analysis on Italian Agritourism. Agriculture 2019, 9, 42. [CrossRef]

25. Sintori, A.; Liontakis, A.; Tzouramani, I. Assessing the Environmental Efficiency of Greek Dairy Sheep Farms: GHG Emissions and Mitigation Potential. Agriculture 2019, 9, 28. [CrossRef]

26. Mengui, K.C.; Oh, S.; Lee, S.H. The Technical Efficiency of Smallholder Irish Potato Producers in Santa Subdivision, Cameroon. Agriculture 2019, 9, 259. [CrossRef]

27. Havlíček, J.; Dömeová, L.; Smutka, L.; Řezbová, H.; Severová, L.; Šubrt, T.; Šrédl, K.; Svoboda, R. Efficiency of Pig Production in the Czech Republic and in an International Context. Agriculture 2020, 10, 597. [CrossRef]

28. Gołaś, M.; Sulewski, P.; Was, A.; Kłoczko-Gajewska, A.; Pogodzińska, K. On the Way to Sustainable Agriculture-Eco-Efficiency of Polish Commercial Farms. Agriculture 2020, 10, 438. [CrossRef]

29. Fernández-Uclés, D.; Elfkih, S.; Mozas-Moral, A.; Bernal-Jurado, E.; Medina-Viruel, M.J.; Abdallah, S.B. Economic Efficiency in the Tunisian Olive Oil Sector. Agriculture 2020, 10, 391. [CrossRef]

30. Işgın, T.; Özel, R.; Bilgiç, A.; Florkowski, W.J.; Sevinç, M.R. DEA Performance Measurements in Cotton Production of Harran Plain, Turkey: A Single and Double Bootstrap Truncated Regression Approaches. Agriculture 2020, 10, 108. [CrossRef]

31. Bahta, Y.T.; Jordaan, H.; Sabastain, G. Agricultural Management Practices and Factors Affecting Technical Efficiency in Zimbabwe Maize Farming. Agriculture 2020, 10, 78. [CrossRef]

32. Quesada, V.M.; Blanco, I.D.C.; Maza, F.J. Análisis envolvente de datos aplicado a la cobertura educativa en el departamento de Bolívar-Colombia (2007-2008). Omnia 2010, 16, 77-100.

33. Martič, M.M.; Novakovič, M.S.; Baggia, A. Data envelopment analysis-basic models and their utilization. Organizacija 2009, $42,37-43$.

34. Worthington, A.; Dollery, B. Un estudio empírico de las técnicas de medición de la eficiencia de frontera en el gobierno local. Estud. Gob. Local 2000, 26, 23-52. [CrossRef]

35. Zhonghua, C.; Ye, W. Fronteras de investigación en la medición del desempeño del sector público. Proced. Física 2012, 25, 793-799.

36. Banker, R.D.; Charnes, A.; Cooper, W.W. Some models for estimating technical and scale inefficiencies in data envelopment analysis. Manag. Sci. 1984, 30, 1078-1092. [CrossRef] 
37. Blanco, M.; Bares, L.; Hrynevych, O.; Ferasso, M. Analysis of the Territorial Efficiency of European Funds as an Instrument to Reduce Labor Gender Differences. Economies 2021, 9, 9. [CrossRef]

38. Ferasso, M.; Blanco, M.; Bares, L. A Data Envelopment Analysis of the Impact of European Funds on Environmental Indicators. IJERPH 2021, 18, 2800. [CrossRef]

39. Pérez, M.C.; Blanco, M.; Sánchez, C. Evaluación del impacto de los programas de escuelas taller, talleres de empleo y casas de oficio en la comunidad autónoma de Andalucía. Una propuesta metodológica de evaluación ligada al territorio. Prism. Soc. 2016, $16,0-31$.

40. Blanco, M. Evaluación de las políticas activas de empleo en Andalucía. Rev. Galega Econ. 2016, 25, 49-62. [CrossRef]

41. Carpintero, O.; Naredo, J.M. Sobre la evolución de los balances energéticos de la agricultura española, 1950-2000. Hist. Agrar. 2006, 40, 531-554. 